\title{
Literati at the Académie Française (1635-1793)
}

\author{
David de la Croix
}

IRES/LIDAM, UCLouvain

This note is a summary description of the set of literati who were members of the Académie Française from its inception in 1635 to its (temporary) dissolution by the French Revolutionary Convention in 1793.

\section{The ACADEMY}

The origin story of the Académie Française begins with informal meetings of several literati at the home of Valentin Conrart in 1629. The chief minister to the King, Cardinal Richelieu, sensitive to glory in all its forms, wanted to take these intellectuals under his protection. Taking the Italian academy Accademia della Crusca as a model, Cardinal Richelieu asked that the statutes drawn up by the interested parties be submitted for his approval, that the number of members be increased to forty, and that only talent should be taken in consideration for membership, not birth, fortune or acquired situation. The academy opened officially in 1635, with the approval of the King of France. Academicians had to be concerned with the purity of the language and aimed to make the French language capable of the highest eloquence. The first edition of the dictionary of the Academy was published in 1694. Successive editions shaped the French language and have continued to do so to the present day. The Academy was slow to adjust to the Enlightenment in the 18th century. It was dissolved by the Convention in 1793 and its assets were nationalized.

We may question the rationale for including the members of the language academies, such as those elected at the Académie Française, in our sample of academic scholars and literati. Such academies are not included in the list of academies provided by McClellan (1985) in his work "Science Reorganized", perhaps reflecting the idea that linguistics and grammar are not sufficiently "scientific". We dispute this view and argue that language affects economic and social development (for example, both the long-term orientation (vs. short-termism) and the importance of gender biases are associated with linguistic structures, see Galor, Özak, and Sarid (2020)). Moreover, bringing structure to a common language in heterogeneous countries such as France, Italy and Spain can be important for development. Hence, we survey the Royal Spanish Academy in De la Croix and Duchêne (2021), the Académie Française here, and the Accademia della Crusca in a forthcoming issue. Notice that these three academies have no counterpart in the English and German-speaking countries.

\section{SOURCES}

The website of the Académie Française, https://www.academie-francaise.fr, offers a complete list of its members since its inception, with detailed biographical information. Context and statistics can be found in Caput (1986). For anecdotes, see Pellisson and d'Olivet (1858).

\section{SOME STATISTICS}

Table 1 displays some descriptive statistics. There are 275 literati. The quality of information about them is remarkably high. The year and place of birth is known for almost everyone. All the academicians have a Wikipedia page, and almost all of them have left a footprint in the catalogues of 
the libraries of the world, Worldcat. Expected age at death is the only variable which shows some time variation. The rise from 63.7 (1618-1685) to 68.7 (1686-1733) years fits well the pattern that the mortality of elite groups started to decrease before the economic take-off of the Industrial Revolution (Stelter, De la Croix, and Myrskylä 2021). The drop from 68.7 to 60.9 is related to the violent death of relatively young academicians during the French Revolution (Dupâquier 2000), including Condorcet.

\begin{tabular}{|c|c|c|c|c|c|c|}
\hline \multicolumn{2}{|c|}{ Period } & nb. & $\%$ birth year & mean age & mean age & exp. age \\
\hline Start & End & obs & known & at appoint. & at death & at death \\
\hline 1618 & 1685 & 101 & 99 & 41.1 & 67.2 & 63.7 \\
\hline 1686 & 1733 & 85 & 98.8 & 47.3 & 70.8 & 68.7 \\
\hline 1734 & 1800 & 89 & 100 & 46.5 & 68.8 & 60.9 \\
\hline 1000 & 1800 & $27 \overline{5}$ & $99 . \overline{3}$ & 44.8 & $6 \overline{8} . \overline{8}$ & 64.2 \\
\hline & & & $\begin{array}{c}\% \text { birth place } \\
\text { known }\end{array}$ & $\begin{array}{l}\text { median distance } \\
\text { birth-institution }\end{array}$ & $\begin{array}{c}\% \text { with } \\
\text { Wikipedia }\end{array}$ & $\begin{array}{c}\text { \% with } \\
\text { Worldcat }\end{array}$ \\
\hline 1618 & 1685 & & 97 & 112 & 100 & 99 \\
\hline 1686 & 1733 & & 95.3 & 112 & 100 & 98.8 \\
\hline 1734 & 1800 & & 100 & 149 & 100 & 98.9 \\
\hline 1000 & 1800 & & $\overline{97 . \overline{5}}$ & $11 \overline{5}$ & 100 & 98.9 \\
\hline
\end{tabular}

Table 1: Summary statistics by period

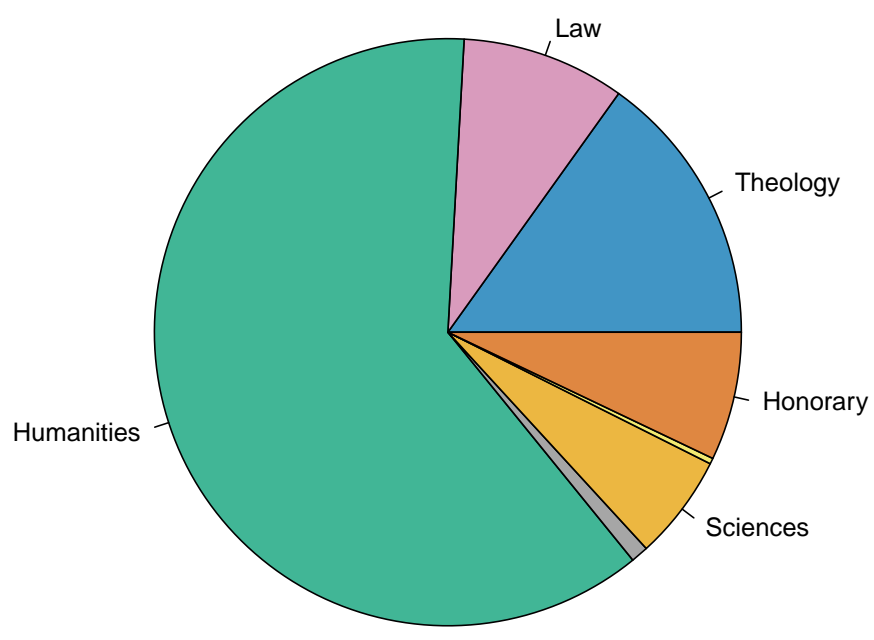

Figure 1: Broad fields at the Académie Française

\section{FIELDS}

Figure 1 shows the relative importance of fields, broadly defined. Unsurprisingly, the main field was humanities. But the other fields were present as well, with the exception of medicine. Besides the active scholars and literati, the "honorary" members were those who were elected to the institution with no clear scientific identity. 


\section{Place OF BIRTH}

Figure 2 is a plot of the places of birth of all the members of the Académie Française. It shows that the academy recruited members from all over France, but not beyond.

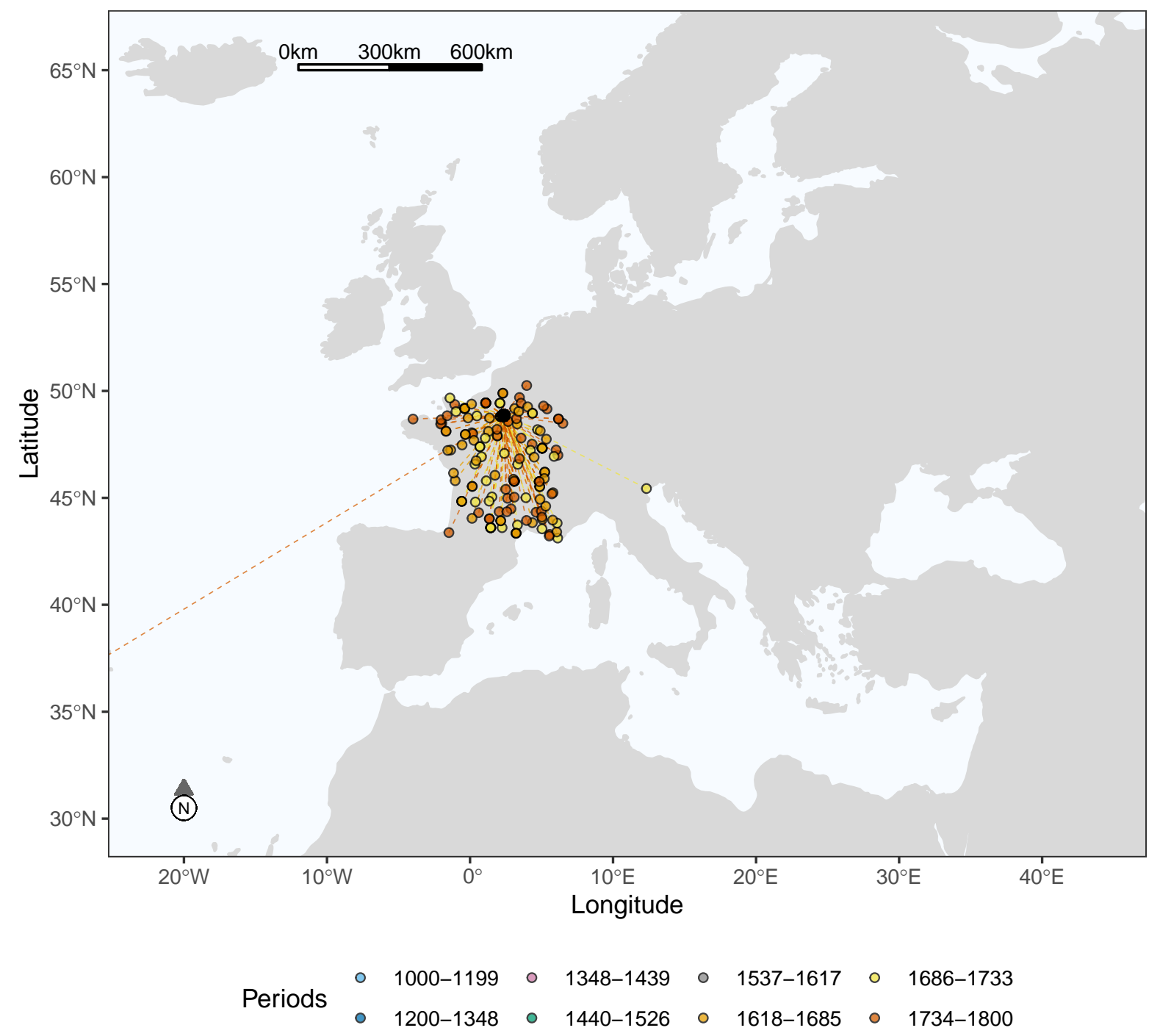

Figure 2: Places of birth of the members of the Académie Française

\section{HUMAN CAPITAL OF LITERATI}

For each person in the database, we compute a heuristic human capital index, identified by combining information from Worldcat and Wikipedia using principal component analysis. Details are given in RETE in volumes 1-5. Figure 3 shows the names of all the literati with a positive human capital index. The vertical green lines (rug plot) show the distribution of all literati, including the obscure ones, over time (counting from the beginning of their active life).

Figure 3 shows that the quality of the Academy is not just due to a few superstars, as there is a mass of very active people just below them. There are very few people with a human capital index below 2 . 


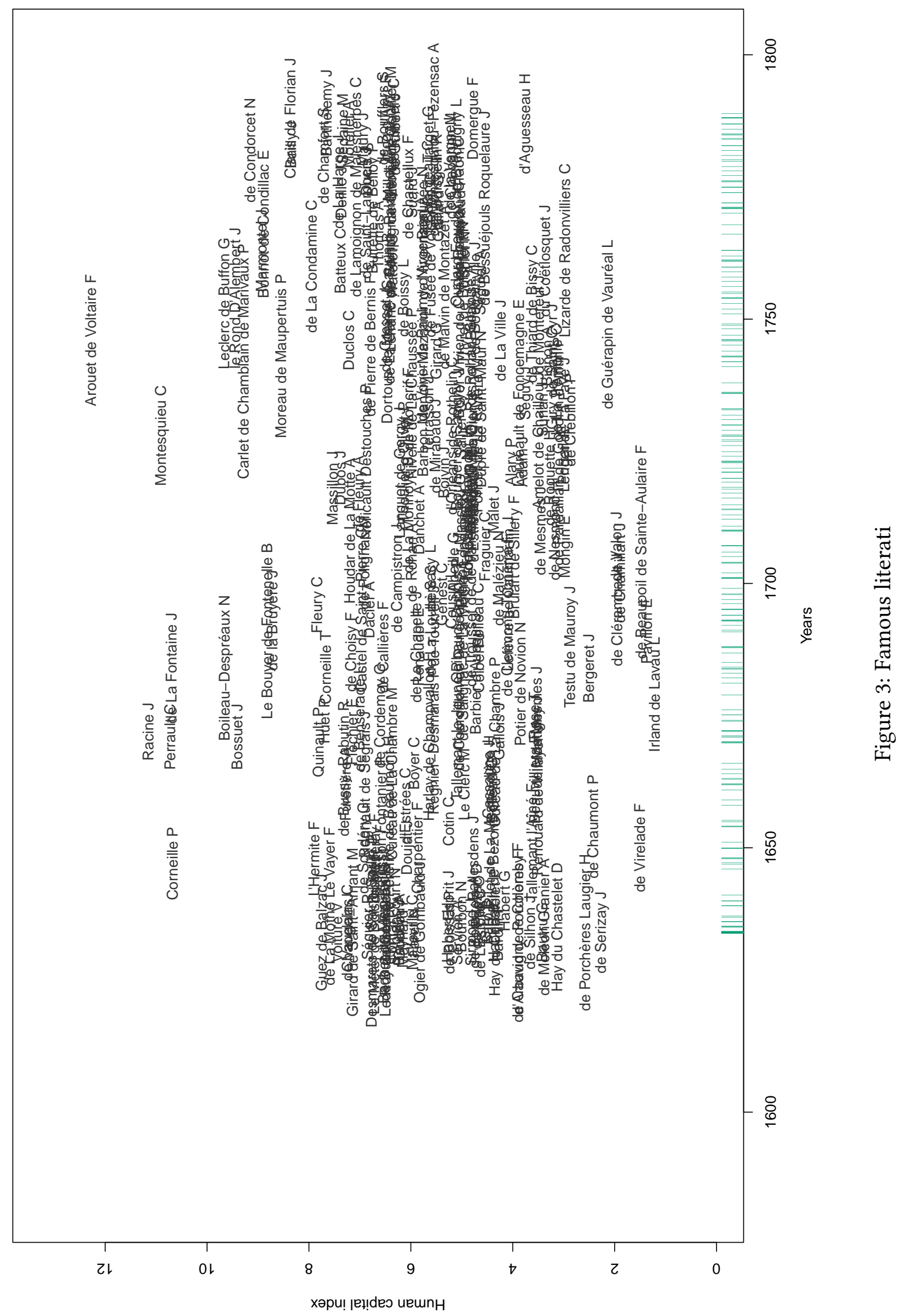




\section{TOP 6 LITERATI}

We provide a brief overview of the six literati with the highest human capital index.

François-Marie Arouet de Voltaire (Paris 1694 - Paris 1778) was a famous French philosopher, historian, and writer. He was member of many academies throughout Europe, including the Saint Petersburg Academy of Sciences (De la Croix and Doraghi 2021) and the National Academy of Sciences, Letters and Arts of Bordeaux (De la Croix and Dock 2021), which we have already surveyed. It took some time for Voltaire to be accepted at the Académie Française. He was probably too modern for this venerable society, and he had many enemies. He was finally elected in 1746. His written output is considerable, both in quantity and quality. He died in 1778 and was refused a Catholic funeral.

Jean Racine (La Ferté-Milon 1639 -- Paris 1699) was elected to the Academy quite young, in 1672. He is known for his literary output including eleven tragedies, such as Andromaque, Britannicus, Iphigénie. He was one of the leaders of the conservatives against the modernizers. His works reflect Jansenist theories: either man has received the divine grace, or he is deprived of it, nothing can change his destiny.

Charles-Louis de Secondat de la Brède et de Montesquieu (Bordeaux 1698 - Paris 1755) was a French political thinker and writer of the Enlightenment. He wrote major works combining history and philosophy, including De l'Esprit des Lois in 1748. He is at the origin of the theory of separation of powers, which is implemented in democracies around the world. He did not participate much in the Académie Française, but was quite involved in the Academy of Bordeaux (De la Croix and Dock 2021).

Charles Perrault (Paris 1628 - Paris 1703) was the iconic French author who laid the foundations for a new literary genre, the fairy tale. The best known of his tales include Le Petit Chaperon Rouge (Little Red Riding Hood), Cendrillon (Cinderella), and La Belle au bois dormant (Sleeping Beauty). His works, mostly derived from European popular tradition, are still very popular today. As an academician, he proposed introducing attendance fees, and pushed to make the reception sessions public. He also proposed secret ballots at the elections. He wrote the preface to the Dictionary of the Academy in 1694.

Jean de La Fontaine (Château-Thierry 1621 - Neuilly-sur-Seine 1695) was a French poet known above all for his fables, which provided models for later fabulists across Europe. It is said that he was a lawyer by training. His texts derive for the most part from the Graeco-Roman antiquity literature (Aesop and Horace). His simple verses can easily be memorised, and often display profound insights into human nature. Many of the lines have entered the French language as standard phrases, often proverbial. He was elected to the academy quite late, in 1684, as the King had reservations about him.

Pierre Corneille (Rouen 1606 - Paris 1684) was an author of French tragedies, probably the greatest. He was a lawyer by training. He presented his first play in 1625. His masterpiece, Le Cid, performed eleven years later, was a huge success. He was elected to the Academy in 1647.

\section{DIVERSITY}

Under the Ancien Regime, women could only enter elected assemblies if the regulations allowed them to do so (some assemblies allowed their presence). Jean le Rond D'Alembert, academician since 1754, proposed in 1760 to reserve 4 of the 40 seats for women in order to promote the candidacy of Julie de Lespinasse. The attempt failed. 


\section{INTERSECTIONS WITH UNIVERSITIES}

Figure 4 shows that very few members of the Academy were also professors at any university. This was probably a standard pattern for France, where academies were often unrelated to universities. More academicians were involved in teaching either at the Royal College (De la Croix 2021) and at the Royal Gardens. Those two institutions, created by the King, provided higher education alongside the University of Paris.

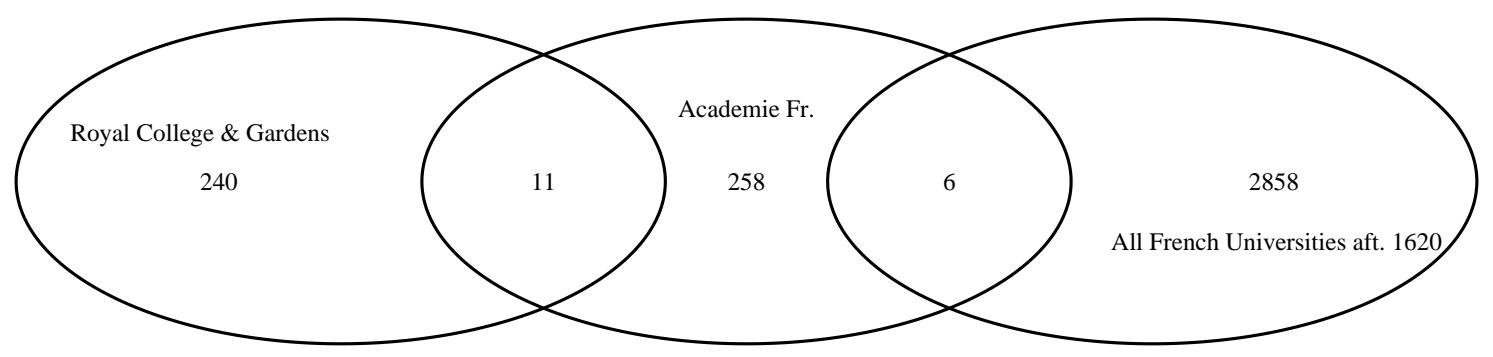

Figure 4: Intersections of the lists of scholars between the Royal College, the University of Paris and the Académie Française

\section{ACKNOWLEDGMENTS}

This project has received funding from the European Research Council (ERC) under the European Union's Horizon 2020 research and innovation programme under grant agreement No 883033 "Did elite human capital trigger the rise of the West? Insights from a new database of European scholars."

First version January 10, 2022.

\section{REFERENCES}

Caput, Jean-Pol. 1986. L'académie française. Paris: Presse Universitaire de France.

De la Croix, David. 2021. Scholars and Literati at the Royal College in Paris (1530-1800). Repertorium Eruditorum totius Europae 1:19-24. https://doi.org/10.14428/rete/v1i0/Royal-College.

De la Croix, David, and Fanny Dock. 2021. Scholars and Literati at the National Academy of Sciences, Letters and Arts of Bordeaux (1712-1793). Repertorium Eruditorum totius Europae 4:9-17. https: //doi.org/10.14428/rete.v4i0/abordeaux.

De la Croix, David, and Mehrdaad Doraghi. 2021. Scholars and Literati at the Saint Petersburg Academy of Sciences (1724-1800). Repertorium Eruditorum totius Europae 5:17-26. https://doi. org/10.14428/rete.v5i0/Petersburg.

De la Croix, David, and Julie Duchêne. 2021. Scholars and Literati at the Royal Spanish Academy (1713-1800). Repertorium Eruditorum totius Europae 3:11-17. https://doi.org/10.14428/rete.v3i0/ aspanish. 
Dupâquier, Jacques. 2000. La mortalité des immortels. Revue des Sciences morales et politiques, 185204.

Galor, Oded, Ömer Özak, and Assaf Sarid. 2020. Linguistic traits and human capital formation. In AEA Papers and Proceedings, 110:309-13. https://doi.org/10.3386/w26699.

McClellan, James E. 1985. Science Reorganized: Scientific Societies in the Eighteenth Century. New York: Columbia University Press. https://doi.org/10.2307/2739060.

Pellisson, Paul, and Joseph d'Olivet. 1858. Histoire de l'académie française. Paris: Didier.

Stelter, Robert, David De la Croix, and Mikko Myrskylä. 2021. Leaders and Laggards in Life Expectancy among European Scholars from the Sixteenth to the Early Twentieth Century. Demography 58:111-135. https://doi.org/10.1215/00703370-8938107. 